\title{
Hubungan Tingkat Depresi Dengan Gangguan Tidur (Insominia) Pada Lansia Di Upt Panti Werdha "Mojopahit" Kabupaten Mojokerto
}

\author{
Corelation Of Depression With Sleep Disorders (Insomnia) The Elderly In Upt Panti \\ Werdha 'Mojopahit'mojokerto Regency
}

\author{
Tria Wahyuningrum*,Noer Saudah**, Lutfi Hermansyah** \\ *Prodi DIII Kebidanan STIKES Bina Sehat PPNI Jl.Gayaman Km 06 \\ **Prodi S1Keperawatan STIKES Bina Sehat PPNI J1 Gayaman Km 06
}

\begin{abstract}
There are two normal processes of the most important in human life what are eating and sleeping. Although both are very important,it is so routine that we often forget it and will process only after a disturbance in the process then we remember the importance of two conditions. Insomnia is a sleep disorder that is the most commonly found. The incidence will increase by age. Approximately $40 \%$ of elderlys complain of insomnia. The research objective analyzed the relationship between the level of depression with sleep disorders (insomnia) of the elderly in UPT Panti Werdha 'Mojopahit' Mojokerto. Design research used analytical correlation with cross sectional approach. The population was 45 respondents Elderly in UPT Panti Werdha 'Mojopahit' Mojokerto. The sample of this research was 32 people whichwas taken by purposive sampling. Data was taken by the interview using instruments KSPBJ GDS 15 and Scale-irs. After the data was done, it was analyzed by data processing and statistical test of Rank Spearman with SPSS version 16.0. The result showed $\rho(0.001)<\alpha(0.05)$, so that $\mathrm{H}_{0}$ was rejected.Itwas a relationship with the depressed levels of sleep disorders (insomnia) the elderly in UPT Panti Werdha 'Mojopahit' Mojokerto,with $r=0.552$, which means the correlation was high, strong. Be advised of the research resultis expected in order to elderly can do physical activity and to practice for prevent occurrence of depression in order to avoid insomnia.
\end{abstract}

Keywords: Level ofdepression, sleepdisorder, elderly, and Insomnia

\section{Pendahuluan}

Bertambahnya perubahan sosial yang terjadi di masyarakat,maka banyak keluarga yang memasukkan anggota keluarga mereka ke panthi werdha dengan berbagai alasan diantaranya perubahan fisik,psikososial dan termasuk salah satunya terdapat gangguan tidur. Menurut Waspada (2007) ada dua proses normal yang paling penting di dalam kehidupan manusia adalah makan dan tidur. Walaupun keduanya sangat penting akan tetapi, karena sangat rutin maka kita sering melupakan akan proses itu dan baru setelah adanya gangguan pada kedua proses tersebut maka kita ingat akan pentingnya kedua keadaan ini. Insomnia merupakan gangguan tidur yang paling sering ditemukan. Kejadiannya makin meningkat seiring bertambahnya usia. Kurang lebih 40\% lansia mengeluh mengalami insomnia. Insomnia adalah keluhan sulit untuk masuk tidur atau sulit mempertahankan tidur (sering terbangun saat tidur) dan bangun terlalu awal serta tetap merasa badan tidak segar meskipun sudah tidur (Puspitosari, 2008).

Faktor psikologis memegang peranan utama terhadap kecenderungan insomnia.Biasanya insomnia disebabkan oleh stres, perubahan hormon, dan kelainan-kelainan kronis.Insomnia yang terjadi dalam tiga malam atau lebih dalam seminggu dalam jangka waktu sebulan termasuk insomnia kronis, salah satu penyebab insomnia kronis adalah depresi (Waluyo, 2010). 
Menurut data dari WHO (World Health Organization) pada tahun 1993, kurang lebih $18 \%$ penduduk dunia pernah mengalami gangguan sulit tidur, dengan keluhan yang sedemikian hebatnya sehingga menyebabkan tekanan jiwa bagi penderitanya (Lanywati, 2001). Indonesia adalah termasuk Negara yang memasuki era penduduk berstruktur lanjut usia (aging structured population) karena jumlah penduduk yang berusia 60 tahun ke atas sekitar 7,18\%. Jumlah penduduk lansia di Indonesia pada tahun 2006 sebesar kurang lebih 19 juta, dengan usia harapan hidup 66,2 tahun. Pada tahun 2010 diperkirakan jumlah lansia sebesar 23,9 juta $(9,77 \%)$, dengan usia harapan hidup 67,4 tahun dan pada tahun 2020 diperkirakan sebesar 28,8 juta (11,34\%), dengan usia harapan hidup 71,1 tahun (Menkokesra, 2008). Tingginya angka lansia membutuhkan perhatian khusus, salah satunya adalah gejala depresi yang sering muncul pada lansia.Gejala depresi ini bisa mengakibatkan dapat memperpendek harapan hidup dengan mencetuskan atau memperburuk kemunduran fisik.Dampak terbesarnya sering terjadi penurunan kualitas hidup dan menghambat pemenuhan tugas-tugas perkembangan lansia.Depresi merupakan masalah mental yang paling banyak ditemui pada lansia.Prevalensi depresi pada lansia di dunia sekitar $8-15 \%$. Hasil survey dari berbagai negara di dunia diperoleh prevalensi rata-rata depresi pada lansia adalah $13,5 \%$ dengan perbandingan pria dan wanita $14,1: 8,5$. Sementara prevalensi depresi pada lansia yang menjalani perawatan di RS dan Panti Perawatan sebesar 30 - $45 \%$ (Stanley dan Beare, 2007). Berdasarkan survei awal pada bulan November 2014 di panthi wredha Majapahit Mojokerto didapatkan 6 dari 10 lansia yang mengatakan kesulitan jika akan tidur dan sering terbangun pada malam hari. Merekajuga mengatakan jika sudah terbangun mereka sulit untuk tidur lagi dan dipagi harinya sering merasa badan tidak segar meskipun sudah tidur.
Berdasarkan survei awal tersebut dapat disimpulkan bahwa kebutuhan tidur lansia yang tinggal di Dinas Sosial Panti Werdha Majapahit Mojokerto adalah terganggu, hal itu kemungkinan disebabkan oleh adanya rasa cemas dan tingkat depresi yang sering mereka alami.dan dari 10 lansia tersebut 4 diantaranya mengatakan bahwa dirinya kesepian dan sering menyendiri dan tidak mau berkumpul dengan teman-temannya,hal ini dapat di simpulkan bahwa rasa sedih yang berkepanjangan dan kurang adanya perhatian memicu terjadinya gejala depresi yang dialami.

Gangguan tidur disebabkan oleh beberapa faktor yaitu psikologis dan biologis, penggunaan obat-obatan dan alkohol, lingkungan yang mengganggu serta kebiasaan buruk, juga dapat menyebabkan gangguan tidur.Faktor psikologis memegang peranan utama terhadap kecenderungan insomnia.Biasanya insomnia disebabkan oleh stres, perubahan hormon, dan kelainan-kelainan kronis.Insomnia yang terjadi dalam tiga malam atau lebih dalam seminggu dalam jangka waktu sebulan termasuk insomnia kronis, salah satu penyebab insomnia kronis adalah depresi (Carpenito, 2000). Menurut Nugroho (2000), stres psikososial yang dialami lansia dapat mengakibatkat kegelisahan yang mendalam, penurunan kondisi fisik, kemarahan yang tak terkendali, bahkan dapat mengakibatkan perasaan depresi.

Dampak serius gangguan tidur pada lansia misalnya mengantuk berlebihan di siang hari, gangguan, mood, depresi, sering terjatuh,dan penurunan kualitas hidup. dari uraian diatas peneliti tertarik untuk meneliti "Hubungan Tingkat Depresi Dengan gangguan tidur (insomnia) pada Lansia di Dinas Sosial Panti Werdha Majapahit Mojokerto".

\section{Metode Penelitian}

Dalam penelitian ini jenis penelitian yang digunakan adalah penelitian analitik korelasi adalah penelitian hubungan antara 
dua variabel pada suatu situasi atau kelompok subjek.

Pada penelitian ini populasinya adalah semua Lansia yang tinggal di Dinas Sosial Panti WerdhaMajapahit Mojokerto

Dalam penelitian ini pengambilan sampel secara Purposive Sampling yaitu teknik untuk menentukan sampel dengan cara memilih sampel diantara populasi sesuai yang dikehendaki peneliti (tujuan / masalah dalam penelitian). Sampel pada penelitian ini adalah sebagian lansia yang tinggal di Dinas Sosial Panti WerdhaMajapahit Mojokerto. Variabel independen pada penelitian ini adalah tingkat depresi lansia. Dalam penelitian ini variabel dependen pada penelitian ini adalah gangguan tidur (insomnia). Instrumen yang digunakan peneliti berupa kuesioner. Dalam penelitian ini peneliti menggunakan skala GDS untuk variabel tingkat depresi dan untuk gangguan tidur peneliti menggunakan kuisioner insomia.

\section{Hasil Penelitian}

Tabel 1 Distribusi Frekuensi Responden Berdasarkan Umur Di Panti Werdha Mojopahit Mojokerto.

\begin{tabular}{lccc}
\hline NO & Umur & Frekuensi (F) & $\begin{array}{l}\text { Prosentase } \\
(\%)\end{array}$ \\
\hline 1 & $60-74$ & 19 & $59,4 \%$ \\
2 & $75-90$ & 13 & $40,6 \%$ \\
\hline & Total & 32 & 100 \\
\hline
\end{tabular}

Berdasarkan tabel 1 didapatkan bahwa lebih dari setengah responden berumur 60-74 sebanyak 19 responden $(59,4 \%)$.

Tabel 2 Distribusi Frekuensi Responden Berdasarkan Jenis Kelamin Di Panti Werdha Mojopahit Mojokerto.

\begin{tabular}{clcc}
\hline NO & $\begin{array}{l}\text { Jenis } \\
\text { Kelamin }\end{array}$ & $\begin{array}{c}\text { Frekuensi } \\
(\mathbf{F})\end{array}$ & $\begin{array}{c}\text { Prosentase } \\
(\mathbf{\%})\end{array}$ \\
\hline 1 & Laki-laki & 9 & $28,1 \%$ \\
2 & Perempuan & 23 & $71,9 \%$ \\
\hline & Total & $\mathbf{3 2}$ & $\mathbf{1 0 0}$ \\
\hline
\end{tabular}

Berdasarkan tabel 2 didapatkan bahwa lebih dari setengah responden berjenis kelamin perempuan yaitu 23 responden $(71,9 \%)$.

Tabel 3 Distribusi Frekuensi Responden Berdasarkan Riwayat Pekerjaan Di Panti Werdha Mojopahit Mojokerto.

\begin{tabular}{llcc}
\hline NO & Pekerjaan & $\begin{array}{c}\text { Frekuensi } \\
(\mathrm{F})\end{array}$ & Prosentase (\%) \\
\hline 1 & Tidak Bekerja & 29 & $90,6 \%$ \\
\hline 2 & Bekerja & 3 & $9,4 \%$ \\
\hline & Total & 32 & 100 \\
\hline
\end{tabular}

Berdasarkan tabel 3 diketahui bahwa sebagian besar responden tidak bekerja yaitu sebanyak 29 responden $(90,6 \%)$.

Tabel 4 Frekuensi Responden Berdasarkan Tingkat Pendidikan Di Panthi Werdha Mojopahit Mojokerto

\begin{tabular}{cccc}
\hline NO & $\begin{array}{c}\text { Pendi } \\
\text { dikan }\end{array}$ & $\begin{array}{c}\text { Frekuensi } \\
(\mathrm{F})\end{array}$ & Prosentase (\%) \\
\hline 1 & Tidak & 27 & $84,4 \%$ \\
& Sekolah & & $12,5 \%$ \\
2 & SD & 4 & $3,1 \%$ \\
3 & SMP & 1 & $0 \%$ \\
4 & SMA & 0 & 100 \\
\hline & Total & 32 & \\
\hline
\end{tabular}

Berdasarkan tabel 4 diketahui bahwa sebagian besar responden tidak sekolah yaitu sebanyak 27 responden $(84,4 \%)$.

Tabel 5 Distribusi Frekuensi Responden Berdasarkan Lama Tinggal Dipanti Werdha Mojopahit Mojokerto

\begin{tabular}{lccc}
\hline NO & $\begin{array}{l}\text { Lama } \\
\text { tinggal }\end{array}$ & $\begin{array}{c}\text { Frekuensi } \\
(\mathrm{F})\end{array}$ & $\begin{array}{c}\text { Prosentase } \\
(\%)\end{array}$ \\
\hline 1 & $1-12$ bulan & 1 & $3,1 \%$ \\
2 & $1-4$ tahun & 10 & $31,2 \%$ \\
3 & $>4$ tahun & 21 & $65,6 \%$ \\
\hline & Total & 32 & 100 \\
\hline
\end{tabular}

Berdasarkan tabel 5 didapatkan bahwa lebih dari setengah responden menurut lama tinggal yaitu $>4$ tahun sebanyak 21 responden $(65,6 \%)$. 
Tabel 6 Distribusi Frekuensi Responden Berdasarkan Tingkat Depresi Dipanti Werdha Mojopahit Mojokerto.

\begin{tabular}{cccc}
\hline NO & $\begin{array}{c}\text { Tingkat } \\
\text { Depresi }\end{array}$ & $\begin{array}{c}\text { Frekuensi } \\
(\mathbf{F})\end{array}$ & $\begin{array}{c}\text { Prosentase } \\
(\boldsymbol{\%})\end{array}$ \\
\hline 1 & Ringan & 16 & $50 \%$ \\
\hline 2 & Sedang & 12 & $37,5 \%$ \\
3 & Berat & 4 & $12,5 \%$ \\
\hline & Total & $\mathbf{3 2}$ & $\mathbf{1 0 0}$ \\
\hline
\end{tabular}

Berdasarkan tabel 6diketahui bahwa setengah dari responden pada tingkat depresi ringan yaitu 16 responden $(50 \%)$.

Tabel 7 Distribusi Frekuensi Responden Berdasarkan Gangguan Tidur (Insomnia) Dipanti Werdha Mojopahit Mojokerto

\begin{tabular}{llcc}
\hline NO & $\begin{array}{l}\text { Gangguan } \\
\text { Tidur } \\
\text { (insomnia) }\end{array}$ & $\begin{array}{c}\text { Frekuensi } \\
(\mathrm{F})\end{array}$ & $\begin{array}{c}\text { Prosentase } \\
(\%)\end{array}$ \\
\hline 1 & Tidak ada & 5 & $15,6 \%$ \\
keluhan & Ringan & 23 & $71,9 \%$ \\
3 & Berat & 1 & $3,1 \%$ \\
4 & Sangat berat & 3 & $9,4 \%$ \\
\hline & Total & 32 & $100 \%$ \\
\hline
\end{tabular}

Berdasarkan tabel 7 diketahui bahwa lebih dari setengah responden pada gangguan tidur (insomnia) ringan yaitu 24 responden $(71,9 \%)$.

Tabel 8 Tabulasi Silang Hubungan Tingkat Depresi Dengan GangguanTidur (Insomnia) Pada Lansia DiPanti Werdha Mojopahit Mojokerto

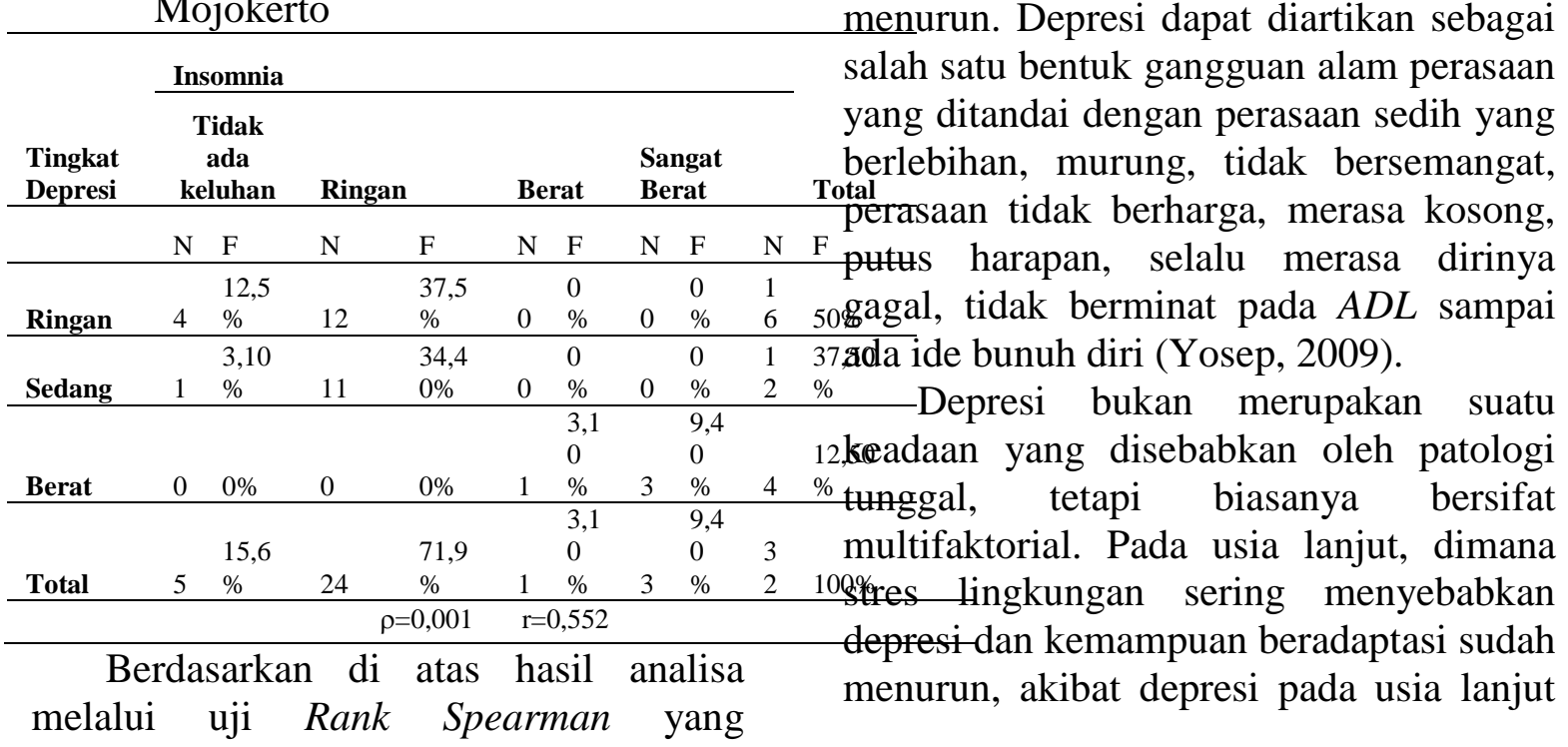

(Statistical Package for the Social Sciences) versi 16.0,diperoleh hasil $(\rho=0,001<\alpha=0,05)$ maka $\mathrm{H}_{0}$ ditolak dan $\mathrm{H}_{1}$ diterima berarti "Ada Hubungan tingkat depresi dengan gangguan tidur (insomnia) pada Lansia di Panti Werdha Mojopahit Kabupaten Mojokerto". Dengan nilai koefisien korelasi $\mathrm{r}=0,552$ yang artinya korelasi yang tinggi, kuat.

\section{Pembahasan}

Hasil penelitian disajikan sesuai dengan tujuan penelitian yang telah disusun sebelumnya.Pembahasan menguraikan antara fakta, teori dan opini peneliti.

\section{Tingkat depresipada Lansia}

Berdasarkan table 4.6 dengan di tunjukkan dengan skor GDS 15 menunjukkan bahwa setengah dari responden mengalami depresi ringan sebanyak 16 responden (50\%).

Depresi adalah suatu perasaan sedih dan pesimis yang berhubungan dengan suatu penderitaan. Dapat berupa serangan yang ditujukan pada diri sendiri atau perasaan marah yang dalam (Nugroho,2000). Suatu jenis gangguan alam perasaan atau emosi yang disertai komponen psikologik: rasa susah, murung, sedih, putus asa, dan tidak bahagia, serta komponen somatik: anoreksia, konstipasi, kulit lembab (rasa dingin), tekanan darah dan denyut nadi menurun. Depresi dapat diartikan sebagai salah satu bentuk gangguan alam perasaan berlebihan, murung, tidak bersemangat, perasaan tidak berharga, merasa kosong, 7ada ide bunuh diri (Yosep, 2009).

Depresi bukan merupakan suatu 12keadaan yang disebabkan oleh patologi multifaktorial. Pada usia lanjut, dimana depresi-dan kemampuan beradaptasi sudah menurun, akibat depresi pada usia lanjut

dilakukan dengan menggunakan SPSS 
seringkali tidak sebaik pada usia muda (Yosep, 2009).

Banyak responden yang mengalami depresi ringan, depresi yang mereka alami tidak terlalu menggangu kesehatan fisik dan mentalnya. Pada umumnya depresi yang di alami lansia seperti merasa tergangguoleh bayang-bayang masa lalu yang buruk,nafsu makan menurun dan merasa tidak bisa mengusir msalah hidupnya.depresi yang di alami lansia pada penelitian inidapat di sebabkan peristiwa-peristiwa yang dapat memicu terjadinya depresi seperti kegagalan dalam perkawinan,rasa rindu dengan keluarga yang jarang berkunjung,dan rasa kesepian karena jauh dari anggota keluarganya.

Sedangkan responden yang mengalami depresi berat di sebabkan seringnya gejala-gejala stres yang mereka alami seperti ketakutan,gelisah tidur,dan merasa tidak bahagia.timbulnya depresi tersebut dapat di sebabkan oleh penyakit yang di derita,kematian suami/istri yang sangat mempengaruhi kondisi psikis responden.faktor lain yang memicu terjadinya depresi pada responden adalah perubahan kesehatan,dan perubahan pada status keuangan,akan mempengaruhi pola hidup mereka selanjutnya,terutama bagi responden yang kurang kunjungan/perhatian dari keluarga.Semakin besar kemungkinan mengalamai depresi dikarenakan pearasaan kurang beradaptasi,terbiasa bersama sanak keluarga dan itu membuat lansia sering merasa kesepian dan bisa cenderung terjadi depresi.

\section{Gangguan tidur (insomnia) pada lansia}

Berdasarkan tabel 4.7 dan di tunjukkan dengan skor KSPBJ-IRS lansia yang mengalami gangguan tidur (insomnia) ringansebanyak 24 responden $(71,9 \%)$.

Salah satu perubahan pada lansia adalah perubahan pola tidur. Gangguan tidur disebabkan oleh beberapa faktor, yaitu psikologis dan biologis, penggunaan obat-obatan dan alkohol, lingkungan yang mengganggu serta kebiasaan buruk, juga dapat menyebabkan gangguan tidur. Faktor psikologis memegang peranan utama terhadap kecenderungan insomnia. Biasanya insomnia disebabkan oleh stres, perubahan hormon, dan kelainan-kelainan kronis. Insomnia yang terjadi dalam tiga malam atau lebih dalam seminggu dalam jangka waktu sebulan termasuk insomnia kronis, salah satu penyebab insomnia kronis adalah depresi (Rafknowledge, 2004).

Banyak responden yang mengalami gangguan tidur (insomnia) ringan. Disebabkan gangguan tidur (insomnia) yang mereka alami tidak terlalu menggangu kualitas tidur mereka.bentuk gejala gangguan tidur (insomnia) yang jarang di alami responden tersebut seperti jarang bermimpi buruk,waktu yang di butuhkan untuk tidur tidak terlalu lama,dan tidak merasa segar setelah bangun pagi.terjadinya gangguan tidur (insomnia) tersebut karena responden memiliki kebiasaan buruk tidur di siang hari dalam waktu yang lama,sehingga pada malam hari mereka sulit untuk memjamkan mata dan tidur.

Rasa gelisah sebelum tidur dan rasa tidak segar setelah bangun dari tidur terjadi karena adanya penyakit fisik yang di derita seperti rasa pusing karena darah tinggi,sering berkemih pada malam hari,rasa gatal pada salah satu bagian tubuh,penyakit fisik dan kegelisahan lansia tersebut tidak terlepas dari pengaruh faktor usia yang telah lanjut. Seperti perubahan pada sistem genitourinaria yang mengakibatkan kapasitas kandung kemih menurun sehingga sering berkemih pada malam hari dan perubahan sistem integumen yang menyebabkan penurunan perlindungan terhadap suhu yang ekstrim serta berkurangnya sekresi minyak alami dan keringat sehingga pada saat bangun tidur responden kurang merasa segar karena tidur yang terganggu. 
3. Analisa Hubungan Tingkat Depresi dengan Gangguan Tidur (Insomnia) pada Lansia di Panti Werdha Mojopahit Kabupaten Mojokerto

Berdasarkan tabel 4.8 Dari hasil uji statistik dengan menggunakan Rank Spearman di peroleh nilai $\rho=0,001$ dengan $\alpha=0,05$ sehingga $\rho<\alpha$, maka $\mathrm{H}_{0}$ ditolak dan $\mathrm{H}_{1}$ diterima, berarti "Ada Hubungan tingkat depresi dengan gangguan tidur (insomnia)pada Lansia di Panti Werdha Mojopahit Mojokerto. Dengan nilai koefisien korelasi $\mathrm{r}=0,552$ yang artinya korelasi yang tinggi, kuat.

Menurut Rafknowledge (2004), stres psikologis yang dialami oleh lansia juga dapat menyebabkan kesulitan tidur atau insomnia serta dapat mempengaruhi kosentrasi dan kesiagaan, dan juga meningkatkan resiko-resiko kesehatan, serta dapat merusak fungsi sistem imun.Adanya hubungan tingkat depresi dengan gangguan tidur (insomnia) pada lansia karena responden yang mengalami depresi berat cenderung mengalami insomnia berat.Hal ini dapat terjadi karena akibat depresi yang di alami mengganggu pikiran para lansia, sehingga sering terbangun di malam hari dan sulit untuk tidur kembali.depresi yang mereka alami juga berdampak pada penyakit fisik lansia seperti sakit kepala,darah tinggi dan lailain yang dapat menyebabkan terjadinya gangguan tidur pada lansia.

Bagi lansia yang mengalami depresi sedang dan terjadi insomnia ringan di sebabkan karena faktor pemicu depresi yang terjadipada lansia cukup menggangupikiran dan aktivitas lansia seperti status kesehatan yang semakin menurun serta kurang perhatian dari keluarganya.Menurunnya status kesehatan membutuhkan banyak biaya untuk pengobatan sedangkan kondisi keuangan mereka tidak memungkinkan untu membiayai pengobatan tersebut.hal ini tentunya menjadi beban pikiran bagi lansiadan mereka tidak bisa istirahat dan tidur dengan tenang.

\section{Simpulan}

Berdasarkan hasil penelitian yang dilakukan pada tanggal 13-15 Juni 2015 di Panti Werdha Mojopahit Mojokerto, maka dapat disimpulkan sebagai berikut:

1. Tingkat depresi pada lansia di Panti Werdha Mojopahit Mojokerto yaitu setengah dari responden mengalami depresi ringan.

2. Gangguan tidur (insomnia) pada lansia di panti werdha mojopahit mojokerto lebih dari setengah responden mengalami gangguan tidur (insomnia) yang ringan.

3. Terdapat Hubungan Tingkat Depresi Dengan Gangguan Tidur (Insomnia) pada Lansia di Panti Werdha Mojopahit Kabupaten Mojokerto.

\section{Saran}

\section{Bagi Responden}

Lansia harus lebih sering dan aktif melaksanakan aktivitas sehari-hari dan juga dapat melakukan aktivitas lainnya seperti jogging, senam lansia, pengajian dan kegiatan-kegiatan lainnya. Pertahankan untuk terus melakukan aktifitas setiap hari jangan pernah tergantung pada orang lain jika masih sanggup melakukannya sendiri dengan seperti itu diharapkan lansia dapat menjalani hari tua dengan rasa nyaman, dan menyenangkan.

\section{Bagi Petugas Kesehatan}

Dapat melakukan kegiatan senam secara rutin dan mengadakan banyak kegiatan yang bersifat menghibur para lansia agar lansia mau mengikuti kegiatan yang ada secara rutin dan membuat jadwal kegiatan bagi lansia.

\section{Bagi Peneliti Selanjutnya}

Hasil penelitian ini bisa dijadikan pertimbangan untuk dilakukan penelitian lanjutan dengan mengkaji faktor-faktor lain yang berhubungan dengan depresi dan faktor-faktor lain yang berhubungan dengan gangguan tidur (insomnia). 


\section{Daftar Pustaka}

Asmadi. 2008. Konsep dan Aplikasi Kebutuhan Dasar Klien. Jakarta: Salemba Medika.

Azizah, Lilik Ma'rifatul. 2011. Keperawatan Lanjut Usia.(Ed. Ke-1). Yogyakarta: Graha Ilmu.

Carpenito, Linda Juall. 2000. Buku Saku Diagnosa Kperawatan. Edisi 8. Jakarta:Penerbit buku kedokteran EGC

Hasan, F, Abdillah. 2010. The Power of Tidur. Jakarta : PT. Buku Kita

Hidayat, A. A. 2007. Riset Keperawatan dan Teknik Penulisan Ilmiah. Jakarta. Salemba Medika.

Hidayat, A. A. 2009. Metode Penelitian Kebidanan \& Tehnik Analisa Data.Jakarta: Salemba Medika.

Kaplan dan Sadock.1997.Sinopsis Psikiatri Ilmu Pengetahuan Perilaku Psikiatriklinis.Edisi VII. Jilid II. Bina Aksara: Jakarta.

Kumalasari...[et al.]; editor edisi bahasa Indonesia, Monica Ester, Devi

Lanywati, Endang.Gangguan Sulit Tidur. Kanisius. Yogyakarta.

LP2M. 2010. Stikes Bina-S. 2000.Insomnia ehat. Mojokerto: PPNI.

Lumbantobing.2004.

Gangguan

tidur.Jakarta Fakultas

KedokteranUniversitas Indonesia.

Maryam Siti, dkk. 2008. Mengenal Usia Lanjut dan Perawatannya. Jakarta. Penerbit : Salemba Medika

Maslim, Rusdi. 2002. Buku Saku Diagnosis Gangguan Jiwa (PPDGJ III).Jakarta : FK Jiwa Unika Atmajaya

Menkokesra.2008. Lansia Masa Kini danMendatang. (online). (http://www.menkokesra.go.id, diakses pada 29Agustus 2008).Situs resmi kementeriankoordinator bidang kesejahteraanrakyat.

Nevid, Jeffrey S, dkk. 2005. Psikologi Abnormal Edisi Kelima Jilid 2. Erlangga: Jakarta

Notoatmodjo. 2005. Metodelogi Penelitian Kesehatan. Jakarta: PT. Rineka Cipta.

Notoatmodjo.2007. Metodelogi Penelitian Kesehatan. Jakarta: PT Rineka Cipta.
Notoatmodjo, S. 2010. Metodologi Penelitian Kesehatan. Jakarta: Rineka cipta

Nugroho, Wahyudi. SKM. 2000. Keperawatan Gerontik Edisi Ke-2. Jakarta: EGC

Nugroho, W. 2008, Keperawatan Gerontik dan Geriatrik, Penerbit EGC, Jakarta.

Nursalam. 2003. Konsep Penerapan Metodologi Penelitian Ilmu Keperawatan.(Edisi Pertama). Jakarta: Salemba Medica

Nursalam. 2008. Konsep dan Penerapan Metodologi Penelitian Ilmu Keperawatan. Jakarta. Salemba Medika.

Patricia A. Buku ajar fundamental keperawatan: konsep, proses dan praktik/ Patricia A. Potter, Anne Griffin Perry; alih bahasa, Renata

Potter., Perry. 2006. Fundamental Keperawatan. Vol: 2. Jakarta : EGC.

Prasetyono, D.S. 2009. Metode Mengatasi Cemas dan Depresi.Oryza : Yogyakarta

Pudjiastuti Sri Surini, dkk. 2003. Fisioterapi pada lansia. Jakarta. Penerbit Buku: EGC.

Rafknowledge. 2004. Insomnia dan Gangguan Tidur Lainnya. PT Elex MediaKomputindo. Jakarta

Schimeilpfering, 2009.94\%Penduduk Indonesia Depresi.[Online].Diambil tanggal 14 Mei 2009. Diambil dari http://id.ibtimes.com/technology/

Setiadi. 2007. Konsep \& Penulisan Riset Keperawatan. Yogyakarta: Graha ilmu.

Stanley, M \& Bear, P. 2007. Buku Ajar Keperawatan Gerontik. Jakarta: EGC.

Tamher, S. danNoorkasiani.2009.Kesehatan Usia Lanjut dengan Pendekatan. Asuhan Keperawatan. Jakarta: Salemba Medika

Tarwoto \& Wartonah, 2006.Kebutuhan Dasar Manusia \& Proses Keperawatan, edisi 3. Jakarta: Salemba Medika.

Teddy, Hidayat, dr, Sp.K.J. Konsultasi Kesehatan Jiwa'. Harian Umum Pikiran Rakyat. April 2008

Turana.2007. Gangguan Tidur:Insomnia. http://Medicaholistic.com/2007/11/28. Medika.html 
Waluyo, S, 2010. 100 Question \& Answer

Osteoporosis.Jakarta : kelompok

Gramedia, PT. Elex Media

Komputindo.

Waspada.2007. Empat Belas Masalah

Kesehatan Utama Pada

Lansia.http://www.waspada.co.id/index

2.php/option=com_content $\&$ dopdf $=1 \&$

id=3182. Diakses: 24 Januari 2011.

Yosep, I. 2009. Keperawatan Jiwa. Bandung: Refika Aditama

Yulianti, Intan Parulian. - Ed.4.- Jakarta: EGC; 2005 